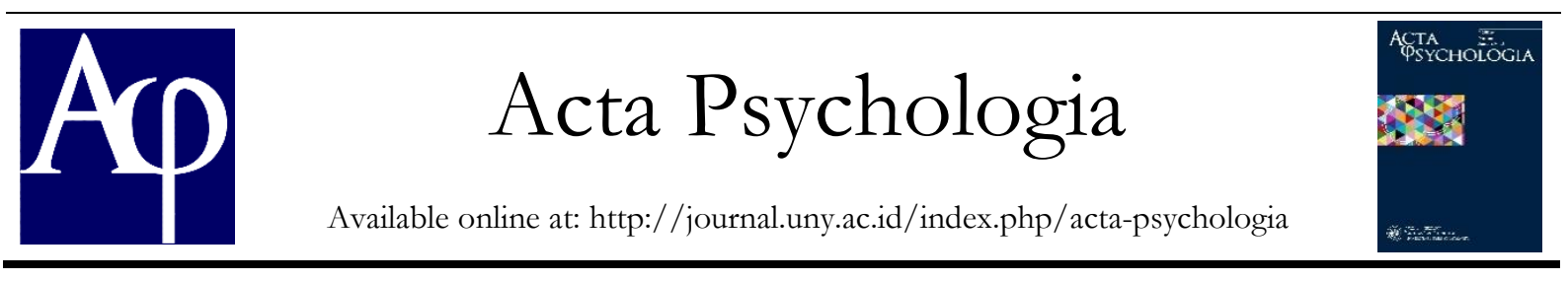

\title{
Intensi Turnover pada Perusahaan Perhotelan : Sebuah Kajian Beban Kerja sebagai Determinan
}

\author{
Nanda Sagita Arifani, Rosita Endang Kusmaryani \\ Jurusan Psikologi, Fakultas Ilmu Pendidikan, Universitas Negeri Yogyakarta; \\ Jl. Colombo No. 1 Sleman Yogyakarta, 55281 \\ nanda.sagitarifani@gmail.com
}

\begin{abstract}
Abstrak
Penelitian ini bertujuan untuk mengetahui pengaruh beban kerja terhadap intensi turnover pada karyawan. Penelitian ini menggunakan pendekatan kuantitatif dengan jenis penelitian ex-post facto. Subjek dalam penelitian ini yaitu 53 karyawan tetap di hotel X di Yogyakarta. Instrumen yang digunakan dalam penelitian ini yaitu skala beban kerja dan skala intensi turnover. Analisis dilakukan dengan uji regresi tunggal. Hasil penelitian menunjukkan bahwa: (1) beban kerja berpengaruh terhadap intensi turnover dengan nilai F sebesar 11,443 ( $\mathrm{p}=0,00)$ dan $\mathrm{R}^{2}$ sebesar 41,2\%; (2) beban waktu secara parsial berpengaruh secara positif terhadap intensi turnover dengan nilai t sebesar $2,112(p=0,04) ;(3)$ beban usaha mental berpengaruh secara positif signifikan terhadap intensi turnover dengan nilai t sebesar 4,556 $(p=0,000)$; (4) beban tekanan psikologis berpengaruh secara positif signifikan terhadap intensi turnover dengan hasil t sebesar 2,580 $(\mathrm{p}=0,013)$. Dengan demikian dapat disimpulkan bahwa beban kerja mampu memprediksi intensi turnover pada karyawan.
\end{abstract}

Kata Kunci: beban kerja, intensi turnover, karyawan

\begin{abstract}
This study aims to determine the effect of workload on turnover intention of X Hotel Yogyakarta's employee. This research used a quantitative approach and included ex-post facto research. Subjects in this study were 53 permanent employees at X Hotel Yogyakarta. Instrument used in this study are workload scale and a turnover intention scale. The results of the analysis showed that: (1) workload affects turnover intention with the results of the $F$ test count $11,443(\mathrm{p}=0,00)$ and $\mathrm{R}^{2}$ is $41.2 \%$; (2) time load had a positive and significant effect on turnover intention with the result of t count $2,112(\mathrm{p}=0,04)$; (3) mental effort load had a positive and significant effect on turnover intention with the result of t count 4,556 ( $\mathrm{p}=0,000)$; (4) psychological stress had a positive and significant effect on turnover intention with the result of $t$ count $2,580(\mathrm{p}=0,013)$. Thus it can be concluded that workload can predict the turnover intention of employee.
\end{abstract}

Keywords: workload, turnover intention, employee

\section{Pendahuluan}

Sumber daya manusia merupakan salah satu hal yang dapat berpengaruh dalam suatu perusahaan. Sumber daya manusia yang dimaksud dalam hal ini adalah karyawan yang berperan sebagai motor penggerak dalam perusahaan. Karyawan dalam perusahaan memiliki peran penting karena dapat menjadi penentu kemajuan sebuah perusahaan. Perusahaan perlu untuk memberikan perhatian pada karyawan untuk meminimalisir terjadinya pergantian karyawan. Pergantian karyawan dari perusahaan akan berpengaruh pada kelangsungan suatu perusahaan. Terjadinya pergantian karyawan akan berdampak positif yaitu perusahaan akan mendapatkan karyawan baru yang lebih baik dari karyawan yang keluar. Namun, ketika keinginan karyawan terhadap perusahaan 
tidak terpenuhi, maka mereka cenderung untuk keluar dari perusahaan. Fenomena seperti ini dapat disebut sebagai perpindahan kerja (turnover) yang akan mempengaruhi kinerja dalam suatu perusahaan.

Turnover yang terjadi memang banyak ditemukan pada perusahaan yang terletak di kota-kota besar di Indonesia seperti halnya Yogyakarta. Sugiarto (2018) menjelaskan dalam penelitiannya bahwa berdirinya perusahaan baru akan memberikan angin segar kepada karyawan untuk mencoba peruntungan baru. Seiring dengan perkembangan hotel di Yogyakarta, ditemukan bahwa fenomena turnover terjadi pada beberapa hotel di Yogyakarta.

Hotel yang merupakan perusahaan yang menyediakan pelayanan jasa penginapan, penyedia makanan dan minuman yang berupa restoran serta fasilitas jasa lainnya tampak jelas mengalami persaingan yang sangat ketat akhir-akhir ini. Peningkatan persaingan ini memberikan konsekuensi selain bersaing dalam hal memberikan pelayananan kepada para tamu, juga bersaing untuk mendapatkan karyawan yang terbaik. Oleh karena itu, masalah ini menjadi titik kritis adalah terjadinya turnover karyawan di beberapa hotel di Yogyakarta. Terjadinya turnover yang terjadi pada salah satu hotel pada tahun 2018 bahkan ada yang mencapai 20\%-30\%. Angka tersebut tentu saja menyebabkan adanya ketidakseimbangan antara keluar masuknya karyawan dengan ketersediaan karyawan pada hotel. Adanya tuntutan pelayanan yang harus dilakukan, sementara karyawan yang menangani hal itu terbatas karena banyak yang keluar dari perusahaan

Seorang karyawan yang melakukan turnover diawali oleh suatu kondisi yang disebut dengan intensi turnover atau keinginan karyawan untuk keluar dari perusahaan (Widjaya et al, 2006). Menurut Mobley (dalam Melky, 2015) intensi turnover merupakan suatu keinginan dari seseorang untuk meninggalkan tempat kerja dengan tujuan mencari pekerjaan lain dan organisasi melakukan penghentian keanggotaan kepada karyawan tersebut. Ada beberapa aspek yang digunakan untuk mengukur intensi turnover. Mobley (1986) mengembangkan tiga aspek pengukuran intensi turnover yaitu berfikir untuk keluar (thinking of quitting), niat untuk mencari alternatif (intention to search for alternatives), dan niat untuk keluar (intention to quit).

Berfikir untuk keluar (thinking of quitting) terjadi ketika karyawan memiliki pikirian untuk keluar dari pekerjaan atau tetap bekerja. Hal tersebut berawal dari ketidakpuasan karyawan, kemudian karyawan akan memiliki pikiran untuk keluar dari pekerjaannya. Niat untuk mencari alternatif (intention to search for alternatives terjadi ketika karyawan memiliki keinginan untuk mencari pekerjaan di perusahaan lain. Apabila karyawan sudah berpikir untuk pindah dari pekerjaannya, maka yang dilakukan karyawan selanjutnya adalah mencoba untuk mencari pekerjaan pada perusahaan lain. Niat untuk keluar (Intention to quit) terjadi ketika karyawan yang memiliki niat untuk keluar dari pekerjaannya akan menunjukkan perilaku tertentu yang menunjukkan keinginan untuk keluar dari perusahaan tersebut.

Intensi turnover ini dapat menjadi prediktor terjadinya turnover. Beberapa karyawan yang sudah tidak mengalami kepuasan di tempat kerja akan melakukan intensi turnover, yang pada kondisi tertentu akan berlanjut ke real turnover. Tingkat turnover yang tinggi dapat berakibat pada terganggunya aktivitas usaha, masalah moral pada karyawan yang tetap memutuskan berada dalam organisasi, dan biaya dalam berbagai hal misalnya rekrutmen dan pelatihan karyawan yang menggantikan posisi yang ditinggalkan. Jika orang yang tepat meninggalkan pekerjaannya tentu saja akan berdampak pada penurunan kinerja organisasi.

Intensi turnover disebabkan oleh beberapa variabel seperti stres kerja, beban 
kerja, dan lingkungan kerja nonfisik (Qureshi, 2013, Riani \& Putra pada tahun 2017); kepuasan kerja dan komitmen organisasi (Melky, 2015). Beban kerja dalam hal ini merupakan salah satu faktor yang berpotensi untuk mempengaruhi intensi turnover. Hal ini diperkuat dengan hasil temuan Irvianti dan Verina (2015) bahwa beban kerja memiliki hubungan yang kuat dan searah dengan intensi turnover.

Gawron (2008) mendefinisikan beban kerja merupakan seperangkat tuntutan tugas, sebagai upaya, dan sebagai kegiatan. Beban kerja berkaitan dengan banyaknya tugas yang perlu untuk diselesaikan oleh seseorang dalam waktu tertentu dalam keadaan normal. Beban kerja dapat berupa beban fisik maupun beban mental. Beban fisik dapat dilihat dari seberapa sering karyawan menggunakan fisiknya untuk bekerja. Di sisi lain, beban mental dapat dilihat dari seberapa besar aktivitas mental yang diperlukan untuk mengingat, konsentrasi, memecahkan permasalahan, serta pengambilan keputusaan.

Reid dan Nygren (dalam Hancoock dan Meshkati, 1988) mendefinisikan bahwa beban kerja merupakan keadaan di mana individu ketika melakukan suatu pekerjaan yang membutuhkan usaha untuk menyelesaikannya. Beban kerja dapat diukur dengan instrumen tertentu. Selanjutnya menurut Reid dan Nygren, beban kerja sebagai tugas-tugas mental pada individu dapat dibuat skala kuantitatif secara subyektif dengan metode pengukuran beban kerja yang dinamakan Subjective Workload Assesment Technique (SWAT). SWAT ini menggambarkan sistem kerja sebagai model multidimensional dari beban kerja, yang terdiri atas tiga dimensi. Tiga dimensi beban kerja tersebut adalah beban waktu (time load), beban mental (mental effort load), dan beban psikologis (psychological stress load). Bentuk multidimensi dari skala SWAT dapat memberikan analisis yang lebih mendalam dibandingkan dengan menggunakan skala tunggal. Beberapa studi sebelumnya menunjukkan bahwa skala SWAT terbukti bermanfaat dalam memperkirakan perubahan beban kerja mental yang dialami oleh karyawan.

Beban waktu (time load) merupakan beban waktu yang berhubungan dengan waktu yang digunakan untuk mengevaluasi seseorang ketika menyelesaikan tugas. Beban waktu tergantung pada ketersediaan waktu yang dibutuhkan pada saat bekerja. Beban usaha mental (mental effort load) adalah tuntutan mental yang dibutuhkan untuk menyelesaikan sebuah pekerjaan. Tuntutan pekerjaan yang membutuhkan konsentrasi disebabkan oleh jumlah informasi yang harus diproses atau kompleksitas tugas. Aktivitas-aktivitas seperti melakukan kalkulasi, membuat keputusan, mengingat atau menyimpan informasi dan pemecahan masalah. Terakhir, beban tekanan psikologis (psychological stress load) merupakan kondisi yang menimbulkan kebingungan, frustasi yang berkaitan dengan kinerja tugas, sehingga membuat penyelesaian tugas menjadi lebih sulit untuk dilaksanakan. Ketiga dimensi tersebut dapat memberikan gambaran secara jelas beban kerja yang dialami karyawan dengan melihat profile dari ketiga dimensi.

Berbagai tuntuan pekerjaan seringkali menimbulkan beban kerja bagi karyawan yang kemudian bermuara pada terjadinya turnover karena karyawan yang bersangkutan memilih untuk keluar dari situasi yang menekan. Semakin banyak beban kerja yang muncul dan kemungkinan terjadi turnover tentu saja akan mempengaruhi produktivitas karyawan bahkan perusahaan.

Berdasarkan paparan tersebut, tampak jelas bahwa beban kerja yang terdiri dari beban waktu (time load), beban usaha mental (mental effort load), dan beban tekanan psikologis (psychological stress load) dapat memberi gambaran tentang pengaruh masing-masing dimensi terhadap intensi 
turnover karyawan. Hal ini tentu saja akan dapat memberikan masukan kepada perusahaan untuk dapat mengantisipasi atau meminimalisir adanya intensi turnover pada karyawan dengan melihat beban kerja karyawan.

\section{Metode Penelitian}

\section{Jenis penelitian}

Pendekatan penelitian yang digunakan yaitu kuantitatif dan jenis penelitian ini adalah ex post facto. Sukardi (2003) menjelaskan bahwa penelitian expost facto merupakan penelitian di mana rangkaian variabel bebas telah terjadi ketika peneliti melakukan pengamatan terhadap variabel terikat.

\section{Subjek Penelitian}

Subjek dalam penelitian ini adalah karyawan dari salah satu hotel berbintang empat yang berlokasi di Yogyakarta. Pengambilan sampel dalam penelitian ini dilakukan dengan total sampling. Total sampling adalah teknik pengambilan sampel dengan jumlah sampel sama dengan populasi. Dalam istilah lain, penelitian ini merupakan penelitian populasi. Dengan demikian semua karyawan perusahaan yang berjumlah 53 orang dilibatkan sebagai subjek penelitian.

Adapun posisi karyawan tersebut adalah karyawan bagian accounting, sales and marketing, Food and Beverage Service, House Keeping, House Keeping, Engineering, Front Office, dan Security. Secara keseluruhan, dari 53 karyawan terdiri dari 21 laki-laki (39\%) dan 32 perempuan (61\%) dengan usia 20 hingga lebih dari 41 tahun.

\section{Teknik pengumpulan data dan instrumen}

Instrumen pengumpulan data yang digunakan dalam penelitian ini adalah Skala Beban Kerja dan Skala Intensi Turnover. Skala yang digunakan yaitu modifikasi skala Likert dengan empat pilihan jawaban. Menurut Cronbach (1970) skala psikologi merupakan pengukuran terhadap performansi yang menjadi karakter seseorang dan cenderung dimunculkan secara tidak sadar dalam bentuk respon terhadap situasi-situasi tertentu yang dihadapi.

Skala Intensi Turnover yang digunakan terdiri dari 20 item. Skala ini dikembangkan dengan merujuk teori Mobley (1986). Skala Intensi Turnover pada penelitian ini memiliki reliabilitas alpha sebesar 0,858. Adapun Skala Beban Kerja dikembangkan dari teori Reid dan Nygren (1988) yang membagi beban kerja menjadi tiga dimensi yaitu beban waktu, beban usaha mental, dan beban tekanan psikologis. Skala ini terdiri dari 20 item dengan reliabilitas alpha sebesar 0,784 (beban wakut); 0,836 (beban usaha mental); dan 0,783 (beban tekanan psikologis)

\section{Teknik Analisis data}

Analisis yang digunakan dalam penelitian ini yaitu analisis statistik deskriptif, uji prasyarat analisis, dan uji hipotesis. Adapun prosedur yang dilakukan dalam penelitian dapat adalah sebagai berikut:

\section{Analisis deskriptif}

Menurut Sugiyono (2013) analisis deskriptif adalah statistik yang digunakan untuk menganalisis data dengan cara mendeskripsikan atau menggambarkan data yang telah terkumpul. Data pada penelitian ini dikategorisasikan berdasar Azwar (2012) mengikuti kategori berikut.

Tabel 1. Norma Kategorisasi

\begin{tabular}{ll}
\hline \multicolumn{1}{c}{ Kategorisasi } & \multicolumn{1}{c}{ Rumus } \\
\hline Sangat Tinggi & $\mathrm{X}>\mu+1,5 \sigma$ \\
Tinggi & $\mu+0,5 \sigma<\mathrm{X} \leq \mu+1,5 \sigma$ \\
Sedang & $\mu-0,5 \sigma<\mathrm{X} \leq \mu+0,5 \sigma$ \\
Rendah & $\mu-1,5 \sigma<\mathrm{X} \leq \mu-0,5 \sigma$ \\
Sangat Rendah & $\mathrm{X} \leq \mu-1,5 \sigma$ \\
\hline
\end{tabular}

Keterangan :

$\mu \quad$ : mean teoritik

$\sigma \quad$ : satuan standar deviasi 
2.Uji prasyarat analisis

Sebelum dilakukan uji hipotesis dengan regresi, dilakukan uji normalitas dan linieritas sebagai prasyarat analisis. Uji normalitas adalah uji yang bertujuan untuk menguji apakah dalam model regresi, variabel pengganggu atau residual memiliki distribusi normal. Perhitungan ini akan dibantu dengan program IBM SPSS Statistics 20 for Windows. Untuk mendeteksi normalitas data dengan uji statistik non parametrik Kolmogorov Smirnov.

Adapun uji linieritas bertujuan untuk mengetahui apakah dua variabel mempunyai hubungan yang linear atau tidak secara signifikan. Pengujian pada SPSS dengan menggunakan Test for Linearity dengan pada taraf signifikansi 0,05

\section{Uji hipotesis}

Uji hipotesis yang digunakan dalam penelitian ini adalah dengan analisis regresi tunggal. Pengaruh variabel-variabel bebas terhadap variabel terikat diuji dengan menggunakan analisis regeresi berganda dengan persamaan kuadarat terkecil dengan metode Ordinary least Squares (pangkat kuadrat terkecil biasa).

Pada pengujian ini, peneliti mengambil kesimpulan berdasarkan uji $\mathrm{F}$ dan uji t. Uji F digunakan untuk mengkaji peran variabel bebas terhadap variabel terikat. Adapun uji $\mathrm{t}$ digunakan untuk mengetahui pengaruh variabel bebas secara independen terhadap variabel tergantung (Ghozali, 2011)

\section{Hasil Penelitian dan Pembahasan}

\section{Hasil analisis deskriptif}

Berdasarkan uji deskriptif, tidak ada karyawan yang memiliki skor intensi turnover $<23,55$ atau kategori sangat rendah dan $<27,85$ atau kategori rendah; sebanyak 2 karyawan (4\%) memiliki skora antara 27,85 hingga $\leq 32,15$ atau kategori sedang; sebanyak 11 karyawan (21\%) memiliki skor antara 32,15 hingga $\leq 36,45$ atau kategori tinggi; dan sebanyak 40 karyawan (75\%) memiliki skor di atas 36,45 atau kategori sangat tinggi. Data tersebut memberikan kesimpulan bahwa sebagian besar karyawan memiliki intensi turnover sangat tinggi (75\%).

Adapun pada data beban kerja secara keseluruhan, tidak ada karyawan yang memiliki skor beban kerja $<28$ atau kategori sangat rendah dan $<36$ atau kategori rendah; sebanyak 11 karyawan (21\%) memiliki skor beban kerja antara 36 hingga $\leq 44$ atau kategori sedang; sebanyak 24 karyawan (45\%) memiliki skor antara 44 hingga $\leq 52$ atau kategori tinggi; dan sebanyak 18 karyawan (34\%) memiliki skor beban kerja di atas 52 atau kategori sangat tinggi. Dari pemaparan tersebut, sebagian besar karyawan menilai beban kerjanya tinggi (45\%) dan sangat tinggi (34\%).

Analisis deskriptif beban kerja dibagi menjadi 3 dimensi yaitu analisis deskriptif beban waktu, beban usaha mental, dan beban tekanan psikologis. Data deskriptif 3 dimensi beban kerja disajikan Gambar 1. Pada gambar 1, sebagian besar karyawan memiliki beban waktu pada kategori tinggi (22 karyawan atau 42\%). Adapun pada dimensi beban usaha mental sebagian besar berada pada kategori sangat tinggi (32 karyawan atau 60\%). Kemudian pada dimensi tekanan psikologis sebagian besar ada pada kategori sangat tinggi (22 karyawan atau $42 \%$ ).

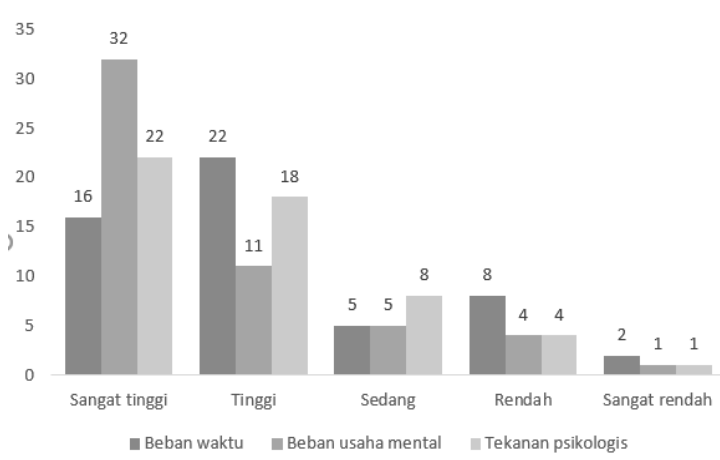

Gambar 1. Data deskriptif dimensi beban waktu, beban usaha mental, dan tekanan psikologis 


\section{Hasil Uji Normalitas}

Berdasarkan uji normalitas dengan Kolmogorov Smirnov signifikansi ( $p$ ) pada beban variabel waktu, beban usaha mental, beban tekanan psikologis, dan turnover $>$ 0,05 . Dengan demikian dapat disimpulkan bahwa data terdistribusi secara normal.

\section{Hasil Uji Linieritas}

Berdasarkan hasil uji linearitas pada baris linearity, nilai $p$ pada beban waktu*intensi turnover yaitu 0,080 ; nilai $p$ beban usaha mental*intensi turnover yaitu 0,000 ; dan nilai $p$ beban tekanan psikologis* intensi turnover yaitu 0,008. Nilai signifikansi $(\phi)$ pada baris linearity $<0,05$. Jadi, hubungan variabel bebas dengan variabel terikatnya dinyatakan linear.

\section{Uji Hipotesis}

Berdasarkan uji analisis dengan regresi berganda, ditemukan nilai korelasi bersama antara dimensi beban waktu, beban usaha mental, dan beban tekanan psikologis dengan intensi turnover sebesar 0,642. Adapun nilai $\mathrm{R}$ square ditemukan 0,412 atau $41,2 \%$. Berdasarkan uji anova, ditemukan nilai $F$ sebesar 11,443 dengan signifikansi (p) $0,000(\mathrm{p}<0,05)$.

Kemudian berdasarkan uji korelasi parsial, beban waktu ditemukan berkorelasi dengan intensi turnover dengan nilai t sebesar $2,111(p=0,000)$. Beban usaha mental juga berkorelasi secara parsial dengan intensi turnover dengan nilai $\mathrm{t}$ sebesar 2,112 $(p=0,040)$. Dimensi tekanan psikologis secara parsial juga berhubungan dengan intensi turnover dengan nilia t sebesar 4,556 $(\mathrm{p}=0,000)$.

\section{Pembahasan}

Berdasarkan hasil analisis regresi yang telah dilakukan, beban kerja secara simultan berpengaruh secara positif dan signifikan terhadap intensi turnover. Hal tersebut dibuktikan dengan hasil analisis uji $\mathrm{F}$ dengan nilai koefisien $\mathrm{F}$ sebesar 11,443 dengan $\mathrm{p}=0,000$. Hasil uji koefisien determinasi diperoleh nilai $\mathrm{R}^{2}$ sebesar
41,2\%. Artinya besar kontribusi yang diberikan oleh beban kerja terhadap intensi turnover adalah sebesar $41,2 \%$. Sisanya sebanyak 58,8\% dipengaruhi oleh variabel lain yang tidak diteliti dalam penelitian ini. Tidak hanya beban kerja, namun ada variabel lain yang berpotensi memiliki pengaruh terhadap intensi turnover seperti stres kerja, gaji, lingkungan kerja, komitmen organisasi, dsb.

Hasil penelitian ini menunjukkan bahwa intensi turnover karyawan hotel dipengaruhi oleh beberapa faktor. Salah satu faktor organisasional yang dapat mempengaruhi intensi turnover yaitu bobot kerja (Mobley, 1986). Bobot kerja yang dimaksud dalam hal ini adalah beban kerja. Hasil penelitian ini juga sesuai dengan temuan Qureshi dkk (2013) yang menunjukkan bahwa beban kerja berkorelasi positif dengan intensi turnover. Semakin tinggi beban kerja maka tingkat intensi turnover juga semakin tinggi.

Terkait dengan uji analisis tersebut, dari analisis deskriptif diperoleh hasil bahwa sebagian besar karyawan memiliki intensi turnover sangat tinggi yang dialami oleh sebanyak $75 \%$ karyawan. Di sisi lain, beban kerja secara keseluruhan juga cenderung tinggi dan sangat tinggi yang dialami oleh $42 \%-60 \%$ karyawan. Tingginya intensi turnover, ternyata juga diikuti dengan tingginya beban kerja karyawan. Hal ini tentu saja perlu mendapat perhatian terkait dengan keberlangsungan operasional hotel karena sedikit banyak kondisi ini mempengaruhi kinerja dalam memberikan layanan kepada para tamu hotel. Untuk itu perlu mengetahui dimensi beban kerja yang secara konsep multidimensional membentuk konstrak variabel beban kerja dan menjadi determinan terhadap intensi turnover karyawan hotel.

Berdasarkan hasil uji t, diperoleh data bahwa beban waktu berpengaruh secara positif dan signifikan terhadap intensi turnover. Hal tersebut dibuktikan dengan hasil uji $\mathrm{t}$ dengan nilai $\mathrm{t}$ sebesar 2,112 $(p=0,04)$. Data deskriptif variabel 
menunjukkan bahwa beban waktu cenderung tinggi dan dialami sebanyak 22 karyawan (42\%). Karyawan yang mengalami beban waktu sebagian besar berada pada rentang usia 20-30 tahun dan didominasi oleh karyawan laki-laki.

Time load dapat terjadi karena beban kerja yang bergantung pada ketersediaan waktu dan tumpang tindih pada saat bekerja (Reid dan Nygreen, 1988). Hal tersebut dapat terjadi ketika seorang karyawan hotel harus bisa menyelesaikan pekerjaan sesuai dengan target yang telah ditentukan. Selain itu, beban kerja ini juga dapat terjadi saat banyak tugas dengan penyediaan waktu yang tidak cukup untuk menyelesaikan tugas tersebut (Barney \& Griffin dalam Hardiani, 2020). Ketika seorang karyawan mengalami beban waktu yang terlalu tinggi, terutama terkait dengan tuntutan pelayanan kemungkinan karyawan tersebut akan memikirkan pekerjaan lain yang memiliki beban kerja yang lebih rendah dari kondisi saat ini. Apabila kondisi pekerjaan, penggunaan waktu kerja, dan standar pekerjaan dinilai baik oleh karyawan, maka kecenderungan berpikir untuk keluar dari pekerjaan akan rendah.

Selanjutnya berdasarkan hasil analisis uji t yang telah dilakukan, beban usaha mental berpengaruh secara positif dan signifikan terhadap intensi turnover. $\mathrm{Hal}$ tersebut dibuktikan dengan hasil uji $\mathrm{t}$ dengan nilai t sebesar 4,556 ( $\mathrm{p}=0,000)$. Data ini didukung dengan hasil analisis deksriptif beban usaha mental yang menunjukkan hasil cenderung sangat tinggi yaitu sebanyak 32 karyawan (60\%). Pada penelitian ini ditemukan bahwa karyawan yang mengalami beban usaha mental sebagian besar berada pada rentang usia 20-40 tahun dan didominasi oleh karyawan laki-laki.

Beban usaha mental dapat terjadi karena tuntutan mental yang diperlukan untuk menyelesaikan sebuah pekerjaan. Beban usaha mental merupakan tuntutan mental yang dibutuhkan untuk menyelesaikan sebuah pekerjaan (Reid dan Nygreen, 1988). Tidak dapat dipungkuri bahwa ketika seorang karyawan mengalami beban usaha mental dalam pekerjaannya, karyawan tersebut akan kurang maksimal dalam penyelesaian pekerjaannya. Ketika hal tersebut terjadi, karyawan yang memiliki intensi turnover yang tinggi akan cenderung mencari alternatif pekerjaan lain yang sesuai dengan dirinya.

Pada dimensi ketiga yaitu beban tekanan psikologis, hasil analisis uji $\mathrm{t}$ menunjukkan bahwa beban tekanan psikologis berpengaruh secara positif dan signifikan terhadap intensi turnover. Hal tersebut dibuktikan dengan hasil uji $\mathrm{t}$ dengan nilai $t$ sebesar 2,580 $(p=0,013)$. Hasil uji hipotesis pada dimensi ini diperjelas dengan hasil data deskriptif pada dimensi beban tekanan psikologis. Hasil analisis menunjukkan bahwa beban tekanan psikologis yaitu sebanyak 22 karyawan $(42 \%)$ dan tergolong sangat tinggi. Pada penelitian ini ditemukan bahwa karyawan yang mengalami beban tekanan psikologis sebagian besar berada pada rentang usia 2030 tahun dan didominasi oleh karyawan laki-laki.

Beban tekanan psikologis mengacu pada kondisi-kondisi yang dapat menyebabkan terjadinya kebingungan, frustasi yang terkait dengan kinerja tugas, sehingga membuat penyelesaian tugas menjadi lebih sulit untuk dilaksanakan (Reid dan Nygreen, 1988). Farhamsyah (2017) menjelaskan bahwa setiap beban kerja yang diterima oleh seseorang harus seimbang baik secara fisik, kemampuan kognitif, maupun keterbatasan manusia yang menerima beban tersebut. Apabila karyawan mengalami beban tekanan psikologis dalam menyelesaikan pekerjaan, maka hal tersebut akan berdampak pada keinginan seseorang untuk pindah ke pekerjaan yang lain.

Secara keseluruhan, beban kerja dan intensi turnover terjadi paling tinggi pada karyawan front office dengan jenis kelamin perempuan. Rata-rata karyawan tersebut bekerja selama $\leq 4$ tahun. Usia karyawan berada antara 20-30 tahun, di mana pada 
usia ini seorang karyawan sedang memasuki tahap entry stage. Pada tahap ini seorang karyawan mulai memasuki organisasi dan biasanya masih sebagai karyawan baru. Seiring dengan bertambahnya usia, karyawan akan memasuki tahapan selanjutnya yaitu mastery stage yang dimulai pada usia 30 tahun. Mastery stage merupakan tahap di mana seorang karyawan ingin mendapatkan jabatan baru karena sudah mempunyai pengalaman pada bidang pekerjaan tertentu dan tidak dipungkiri bahwa karyawan akan memiliki niat untuk keluar dari pekerjaannya untuk mendapatkan pekerjaan baru yang sesuai dengan dirinya.

Posisi front office hotel merupakan posisi yang langsung berhadapan dengan para pelanggan, terutama dalam menerima dan menangani pelanggan dari mulai masuk sampai dengan keluar hotel. Karyawan dituntut untuk menerima dan menangani mereka dengan baik karena hal ini sangat menyangkut nama baik perusahaan secara langsung. Tugas ini yang tampaknya menjadi sorotan terkait dengan beban kerja yang dirasakan karyawan di posisi ini.

Adanya intensi turnover ini menjadi indikator adanya faktor-faktor yang diperkirakan mempengaruhi kepuasan seseorang dalam bekerja serta beban kerja yang dialami. Pemahaman tentang adanya indikasi intensi turnover pada karyawan dapat menjadi sarana bagi perusahaan untuk mendapatkan strategi-strategi baru dalam mengatasi permasalahan ini.

\section{Keterbatasan Penelitian}

1. Saat pengisian skala psikologi, peneliti mengalami keterbatasan dalam melakukan pengendalian dan pengawasan langsung terhadap distribusi instrumen kepada para karyawan karena akan mengganggu kinerja karyawan.

2. Adanya keterbatasan jumlah karyawan sehingga analisis data hanya pada jumlah karyawan yang tersedia secara terbatas dengan beberapa variasi pekerjaan.

\section{Simpulan dan Saran \\ Simpulan}

Beban kerja berpengaruh secara positif dan signifikan terhadap intensi turnover. Hasil uji koefisien determinasi diperoleh nilai $\mathrm{R}^{2}$ sebesar 0,412 yang artinya beban kerja mempengaruhi variabel intensi turnover sebesar $41,2 \%$. Secara parsial, beban waktu, beban mental, dan tekanan psikologis berpengaruh secara positif dan signifikan terhadap intensi turnover pada karyawan hotel.

\section{Saran}

Berdasarkan hasil penelitian yang telah dilakukan, maka peneliti memberikan saran untuk pihak terkait yaitu sebagai berikut:

1. Bagi perusahaan, perlu meningkatkan upaya dalam menyikapi tingkat beban kerja yang tinggi yaitu dengan menambah jumlah karyawan melalui rekruitmen namun dengan sistem baru yang lebih berkualitas.

2. Bagi peneliti selanjutnya, diharapkan peneliti selanjutnya akan lebih mendalam mengkaji perihal pengaruh beban kerja terhadap intensi turnover agar hasilnya lebih akurat dan dapat digeneralisir untuk semua perusahaan ataupun organisasi.

\section{Daftar Pustaka}

Azwar, S. (2012). Penyusunan skala psikologi. Yogyakarta: Pustaka Pelajar.

Cronbach, L. J. (1970). Essentials of Psychological Testing. New York: Happer and Row Publisher.

Farhamsyah, D. (2017). Analisis hubungan beban kerja mental dengan stres kerja di Instalasi CSSD Rumah Sakit Umum Haji Surabaya. The Indonesian Journal of Occupational Safety. 6(1): 107-115.

Gawron, V. J. (2008). Human performance, workload, and situational awareness measures handbook, Second Edition. USA: CRC Press Taylor \& Francis Group. 
Ghozali, I. (2011). Aplikasi analisis multivariate dengan program SPSS. Semarang: Badan Penerbit Universitas Diponegoro.

Hadi, S. (2001). Metodologi research Jilid III. Yogyakarta: Andi Offset.

Hanza, S. R., \& Ingarianti, T. M. (2015). Kematangan karir dengan intensi turnover pada karyawan. Jurnal Ilmiah Psikologi Terapan. 3(2): 308-324.

Hardiani, W. A. A. (2020). Pengaruh work family conflict dan beban kerja terhadap burnout dan dampaknya pada cyberloafing (Studi Pada PT PLN (Persero) Pusat Manajemen Konstruksi. Jurnal Visi Manajemen. 5(1): 651-668.

Irvianti., Laksmi Sito Dwi., Renno Eka Verina. (2015). Analisis Pengaruh Stres Kerja, Beban Kerja dan Lingkungan Kerja terhadap Turnover Intention Karyawan Pada PT XL Axiata Tbk Jakarta. Binus Business Review. 6(1): 117126.

Melky, Yosua. (2015). Hubungan kepuasan kerja dan komitmen organisasi terhadap intensi pindah kerja (turnover intention) karyawan PT. Rejeki Abadi Sakti Samarinda. eJournal Psikologi. 3(3): 694-707

Mobley, W. (1986). Pergantian karyawan: Sebab akibat dan pengendaliannya. Jakarta: PT. Pustaka Binaman Pressindo

Qureishi, M.I., Iftikhar, M., Abbas, S.G., et al. (2013). Relationship between job stress, workload, environment and employees turnover intentions: What we know, what should we know. $W$ orld Applied Sciences Journal, 23 (6): 764- 770, 2013

Reid, G. B., \& Nygren, T. E. (1988). The subjective workload assessment technique: $A$ scaling procedure for measuring mental workload. Dalam N. Meshkati, \& P. A.
Hancock, Human Mental Workload. Elsevier Science Publishers. 185-218.

Riani, N. L. T. \& Putra, M. S. (2017). Pengaruh stres kerja, beban kerja, dan lingkungan kerja non fisik terhadap turnover intention karyawan. E-Jurnal Manajemen Unud. 6(11): 5970-5998.

Sukardi. (2003). Metodologi penelitian pendidikan kompetensi dan prakteknya. Jakarta: Bumi Aksara

Sugiarto, Cahyo. (2018). Pengaruh komitmen organisasi dan perceived organizational support organisasi terhadap turnover intention pada karyawan Hotel Sahid Surabaya. Jurnal Ilmu Manajemen. 6(4): 459-467.

Sugiyono. (2013). Metode penelitian pendidikan pendekatan kuantitatif, kualitatif, dan R※D. Bandung: Alfabeta.

Widjaya D.C., Margarita, F., \& Fenny K. D.W. (2008). Analisis persepsi employee empowerment terhadap employee turnover intention di Hotel X Kupang Nusa Tenggara. Journal Manajemen Perhotelan. 4(2): 72-84. 